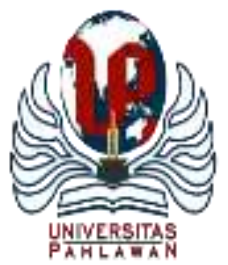

Edukatif : Jurnal Ilmu Pendidikan Volume 3 Nomor 6 Tahun 2021 Halm 4392 - 4399

EDUKATIF: JURNAL ILMU PENDIDIKAN

Research \& Learning in Education

https://edukatif.org/index.php/edukatif/index

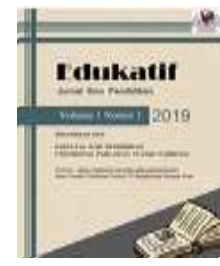

\title{
Analisis Kesulitan Implementasi Pembelajaran Tematik pada Masa Pandemi Covid-19 di Sekolah Dasar
}

\author{
$\operatorname{Irsan}^{1 凶}$, Andi Lely Nurmaya G ${ }^{2}$, Tri Yulan ${ }^{3}$ \\ Universitas Muhammadiyah Buton ${ }^{1,2,3}$ \\ E-mail : $\underline{\text { rsanlely@gmail.com }}^{1}, \underline{\text { nurmaya.aln@gmail.com }}^{2}, \underline{\text { TriYulan@gmail.com }}^{3}$
}

\begin{abstract}
Abstrak
Pada pelaksanaan kurikulum 2013 melalui pembelajaran tematik menekankan siswa berpartisipasi secara aktif dalam kegiatan pembelajaran sehingga diharapkan dapat memperoleh pengalaman langsung dan mengkonstruksi pengetahuannya sendiri sebagai suatu hasil yang dipelajarinya. Oleh karena hal tersebut, tujuan dari penelitian ini adalah untuk menganalisis menganalisis kesulitan implementasi pembelajaran tematik pada masa pandemic covid-19 sekolah dasar. Adapun metode penelitian yang digunakan adalah deskriptif kuantitatif Penelitian ini merupakan penelitian kualitatif dengan pendekatan deskriptif. Teknik pengambilan subjek yaitu teknik purposive sampling. Adapun hasil penelitian diketahui pelaksanaan pembelajaran tematik secara daring terdapat kesulitan diantaranya guru masih belum menggunakan strategi yang sesuai serta mengalami kendala dalam menggunakan media/aplikasi dalam pembelajaran daring sehingga reaksi atau respon siswa kurang antusias/ kurang tertarik dengan materi yang disampaikan oleh guru, masih kurangnya ketersediaan sarana dan prasarana, guru tidak dapat langsung berkomunikasi dengan siswa sehingga siswa harus lebih memahami materi secara mandiri, banyak siswa saat pembelajaran daring akan dilaksanakan belum memiliki smartphone dan akses internet. Begitupula dengan evaluasi atau penilaian pembelajaran tematik dimana guru masih mengalami permasalahan dan kesulitan dalam menilai siswa yang diajar secara daring.
\end{abstract}

Kata Kunci: Implementasi, Pembelajaran Tematik, Sekolah Dasar.

\begin{abstract}
The implementation of the 2013 curriculum through thematic learning emphasizes that students actively participate in learning activities so that they are expected to gain direct experience and construct their own knowledge as a result of what they learn. Because of this, the purpose of this study was to analyze the difficulties of implementing thematic learning during the COVID-19 pandemic in elementary schools. The research method used is descriptive quantitative. This research is a qualitative research with a descriptive approach. The technique of taking the subject is purposive sampling technique. As for the results of the research, it is known that the implementation of online thematic learning has difficulties, including the teacher still does not use the appropriate strategy and experiences problems in using media/applications in online learning so that the reaction or response of students is less enthusiastic/less interested in the material presented by the teacher, there is still a lack of availability. facilities and infrastructure, teachers cannot directly communicate with students so students must better understand the material independently, many students when online learning will be carried out do not have smartphones and internet access. Likewise with the evaluation or assessment of thematic learning where teachers still experience problems and difficulties in assessing students who are taught online.
\end{abstract}

Keywords: Implementation, Thematic Learning, Elementary School.

Copyright (c) 2021 Irsan, Andi Lely Nurmaya. G, Tri Yulan

$\square$ Corresponding author

Email : irsanlely@gmail.com

DOI : https://doi.org/10.31004/edukatif.v3i6.1475 
4393 Analisis Kesulitan Implementasi Pembelajaran Tematik pada Masa Pandemi Covid-19 di Sekolah DasarIrsan, Andi Lely Nurmaya. G, Tri Yulan

DOI: https://doi.org/10.31004/edukatif.v3i6.1475

\section{PENDAHULUAN}

Terjadinya pandemi Covid-19 sangat berdampak pada berbagai aspek kehidupan termasuk pada perubahan tatanan pendidikan di seluruh negara, salah satunya di negara Indonesia. Dalam rangka pencegahan penyebaran Covid-19 dengan berbagai kebijakan pemerintah telah memutuskan bahwa pelaksanaan pembelajaran pada satuan pendidikan harus diterapkan pembelajaran daring. Pembelajaran yang semestinya dilaksanakan di sekolah harus dilaksanakan secara daring dari rumah. Selanjutnya, pembelajaran tematik yang mengharuskan pembelajaran siswa sebagai sentral belajar tentu tidak bisa sejalan dengan semestinya. Padahal dalam Permendikbud No. 65 Tahun 2013 menjelaskan bahwa "Sesuai dengan Kompetensi Lulusan dan Standar Isi maka pembelajaran dilaksanakan untuk menuju pembelajaran terintegrasi”. Hal tersebut tentu menjadi permasalahan yang tidak biasanya dihadapi. Para pemangku pendidikan harus memikirkan hal tersebut untuk memperbaiki pola pendidikan.

Pada Pembelajaran Jarak Jauh (PJJ), Pemerintah menganjurkan agar sekolah-sekolah memetakan pelaksanaan pembelajaran penggunaan secara daring, luring maupun keduanya yang dapat dilaksanakan oleh siswa. Tetapi pada pelaksanaannya tidak terlepas dari kendala, bagi sekolah yang sudah terbiasa melaksanakan pembelajaran berbasis digital atau daring sudah tentu bukan menjadi masalah, apalagi bagi guru yang sudah mahir melakukan penilaian portofolio dengan berbagai tugas yang bervariasi sehingga tidak menjadi beban (Anhusadar, 2021). Akses belajar melalui saluran TVRI juga bukan tanpa kendala, di sebagian wilayah di Indonesia belum memiliki jaringan listrik hingga kesulitan menyesuaikan jadwal materi yang seharusnya diakses karena adanya pemadaman listrik di daerah tersebut. (Sari et al., 2021) Hal ini dikeluhkan juga oleh para orangtua saat mendampingi peserta didik belajar dari rumah merupakan beban tersendiri bagi orangtua yang tidak memiliki sarana dan fasilitas yang memadai hingga latar belakang pendidikan yang cukup. Ini mengakibatkan timbulnya berbagai masalah yang dihadapi pihak sekolah maupun orang tua peserta didik. Proses pembelajaran Online di sekolah dasar berdampak pada guru, siswa dan orang tua (Handarini \& Wulandari, 2020).

Pembelajaran daring merupakan pembelajaran yang menggunakan jaringan internet dengan aksesibilitas, konektivitas, fleksibilitas, dan kemampuan untuk memunculkan berbagai jenis interaksi pembelajaran. Sejalan dengan (Anugrahana, 2020) mengungkapkan bahwa pembelajaran online atau $E$ learning merupakan pembelajaran yang menggunakan rangkaian elektronik (LAN, WAN, atau internet) untuk menyampaikan isi pembelajaran, interaksi atau bimbingan. Pembelajaran Online maupun elearning adalah suatu sistem pelaksanaan Pendidikan jarak jauh yang dilakukan dengan akses jaringan internet(Nurbaeti, Gustiawati, \& Khaldun, 2021). Kondisi pandemi yang mengarahkan proses pembelajaran dilaksanakan secara daring, namun pembelajaran harus tetap terlaksana meskipun pada kenyataannya terdapat berbagai kekurangan dan keterbatasan. Adapun Kekurangan dan keterbatasan yang dihadapkan pada guru dalam proses pembelajaran daring, diantaranya: 1) Pelaksanaan pembelajaran dilakukan full online, materi pelajararan tidak tersampaikan dengan baik kepada siswa, 2) Kesulitan gugu dalam mengimplementasikan pembelajaran secara daring karena keterbatasan kemampuan dalam literasi digital, 3) Sarana dan prasarana serta fasilitas pembalajar yang masih kurang memadai bagi sebagaian guru dalam mengimplementasikan pembelajaran secara daring, 4) Akses jaringan internet yang masih kurang terjangkau.(Wardah \& Farisia, 2021) menjelaskan ada beberapa kelebihan dalam melakukan pembelajaran daring, salah satunya adalah meningkatkan kadar interaksi antara guru dan siswa, pembelajaran dapat dilakukan di mana dan kapan saja, menjangkau peserta didik dalam cakupan yang luas dan mempermudah penyampaian materi pembelajaran. Keuntungan penggunaan pembelajaran daring adalah pembelajaran bersifat mandiri dan interaktivitas yang tinggi, mampu meningkatkan tingkat ingatan, memberikan lebih banyak pengalaman belajar, dengan teks, audio, video, dan animasi yang semua digunakan untuk menyampaikan informasi. Pembelajaran daring menuntut guru untuk menjadi lebih inovatif dan kreatif dalam menyusun langkah-langkah pembelajaran.(Islam \& Antasari, 2021) 
mengatakan hasil belajar dengan pembelajaran model daring lebih baik dari pada hasil belajar tatap muka. Sedangkan penelitian yang lain menyebutkan bahwa hasil belajar yang menggunakan pembelajaran tatap muka lebih baik daripada yang menggunakan pembelajaran daring(Yunitasari \& Hanifah, 2020). Sehubungan dengan hal ini tentunya ada beberapa faktor yang menjadi penyebabnya, salah satu contohnya kita bisa lihat dari kejujuran siswa. Pada pembelajaran daring ada diantara siswa yang melakukan kecurangan dalam menyelesaikan tugas yang diberikan oleh guru yang tidak dapat terhindarkan dengan cara mengawasi siswa saat mengerjakan soal dikarenakan keterbatasan jarak dan waktu, padahal kejujuran menjadi salah satu aspek afektif yang mempengaruhi keberhasilan aspek kognitif siswa.

Pembelajaran tematik adalah pembelajaran terpadu yang menggunakan tema untuk mengaitkan beberapa mata pelajaran sehingga dapat memberikan pengalaman bermakna kepada murid. Tema adalah pokok pikiran atau gagasan pokok yang menjadi pokok pembicaraan ( $\mathrm{Nu}$ et al., 2020). Sejalan dengan hal tersebut, pembelajaran tematik merupakan suatu strategi pembelajaran yang melibatkan beberapa mata pelajaran untuk memberikan pengalaman bermakna kepada peserta didik. Keterpaduan dalam pembelajaran ini dapat dilihat pada proses atau waktu, aspek kurikulum dan aspek belajar mengajar. Pembelajaran tematik merupakan salah satu model pembelajaran terpadu yang merupakan salah satu sistem pembelajaran yang memungkinkan siswa, baik secara individu maupun kelompok aktif menggali dan menemukan konsep serta prinsip-prinsip keilmuan secara holistik, bermakna dan otentik. (Pelajaran, Di, Sains, \& An, n.d.) Tumbuh kembangnya minat dan kebutuhan atas kurikulum terpadu dipicu oleh sejumlah hal sebagai berikut: 1) perkembangan pengetahuan, 2) fragmentasi jadwal pembelajaran, 3) relevansi Pembelajaran tematik hakikatnya mengalihkan persepsi terhadap belajar, dari posisi siswa sebagai objek beralih menjadi subjek dan guru sebagai fasilitator. Hal ini membuat pembelajaran lebih bermakna karena siswa berperan aktif memperoleh ilmu dengan memanfaatkan fasilitas yang disediakan oleh guru. Siswa melakukan sendiri apa yang ingin didapatkannya dengan bekal ilmu yang sudah dimilikinya. Guru hanya memfasilitasi agar siswa bisa mencapai tujuan belajar yang optimal.

Kemampuan guru dalam mengimplementasikan pembelajaran tematik tentunya tidak terlepas dari rancangan rencana pelaksanaan pembelajaran (RPP) yang selanjutnya terlaksana pada kegiatan pembelajaran. Mendukung keterlaksanaan pembelajaran tematik pemerintah berperan penting dalam meningkatkan kompetensi guru diantaranya dengan memberikan pelatihan dan memberikan buku pedoman untuk guru. Kurikulum 2013 dengan pembelajran tematik pada pelaksanaannya menerapkan model pembelajaran berkelompok yang sangat penting dibudayakan di sekolah dasar untuk pengembangan pengetahuan siswa dan soft skill. Melalui pembelajaran ini, diharapkan akan dapat membangun serta meningkatkan berbagai macam sikap positif. Sikap-sikap yang dapat dikembangkan diantaranya adalah sikap tanggung jawab, kerja sama, kepemimpinan, jujur, toleransi, dan sebagainya. Namun, pelaksanaan kebijakan pendidikan dalam masa darurat penyebaran corona virus disease (COVID-19) menganjurkan untuk melaksanakan proses belajar dari rumah melalui pembelajaran daring. Pembelajaran daring dilaksanakan melalui perangkat pendukung yang terhubung dengan koneksi internet seperti komputer atau laptop, gawai, dan alat bantu lain (Batubara, n.d.).

Dalam mengimplementasikan pembelajaran tematik guru diharuskan memiliki peranan penting dan seoptimal mungkin mengikuti pelatihan-pelatihan terkait dengan peningkatan kompetensi dan kemampuan dalam mengajarkan siswa secara daring. Agar pembelajaran tematik tetap berjalan baik pada masa pandemi covid-19, (Alvina, Wandini, Siahaan, \& Siregar, 2021) maka guru diharapkan menggunakan metode pembelajaran yang tepat secara daring sebagai alternatifnya. Berdasarkan hasil wawancara dengan guru di Sekolah Dasar Kota Baubau diketahui beberapa permasalahan yang dihadapi oleh guru dalam pelaksanaan pembelajaran daring. Permasalahan yang terjadi seperti guru masih kesulitan dalam mempersiapkan rencana pelaksanaan pembelajran (RPP) secara daring yang sesuai dan guru juga masih terkendala dalam mengimplementasikan pembelajaran secara daring karena kurangnya pemahaman guru terhadap penggunaan/pemanfaatan teknologi. Selain kendala yang dihadapi oleh guru juga kurangnya fasilitas untuk 
menunjang pembelajaran daring, seperti: tidak semua siswa mempunyai smartphone canggih (kebanyakan siswa meminjam handphone orangtua, kakak maupun saudara); banyak orangtua dari siswa yang sibuk bekerja, sehingga kurangnya bimbingan belajar mengakibatkan mereka kurang disiplin dalam mengikuti pembelajaran daring (sebagai contoh: terdapat siswa yang tidak aktif dalam mengikuti pembelajaran secara daring untuk absen dan keterlambatan dalam mengirim tugas di Whatsapp); sehingga untuk penilaian pembelajaran daring dilakukan dengan pengumpulan buku tugas oleh orangtua ke sekolah, guru mengalami kesulitan memberikan penilaian kepada siswa. Maka Proses pembelajaran daring tidak semudah yang dibayangkan karena terdapat banyak kendala atau permasalahan dalam pelaksanaannya apalagi ini sebagai pengalaman baru dalam sistem pendidikan saat ini.

\section{METODE PENELITIAN}

Penelitian ini merupakan penelitian kualitatif dengan pendekatan deskriptif. Karaktersitik penelitian deskriptif kualitatif yaitu untuk mengeksplor suatu permasalahan atau fenomena sosial serta mengembangkan pemahaman yang spesifik dari suatu fenomena yang diteliti (Education, Dafit, Ramadan, \& Riau, 2020). Subjek pada penelitian ini adalah guru beserta siswa kelas di Sekolah Dasar Kota Baubau. Teknik pengambilan subjek yaitu teknik purposive sampling. Teknik purposive sampling merupakan teknik pengambilan sampel data dengan pertimbangan tertentu.

Pada penelitian ini, data didapatkan berdasarkan hasil observasi, wawancara, dan analisis dokumen. Peneliti melakukan wawancara dengan guru kelas dan siswa Sekolah Dasar Kota Baubau terkait kesulitan yang dialami saat implementasi pembelajaran tematik. Setelah peneliti melakukan kegiatan wawancara, peneliti melakukan kegiatan observasi. Kegiatan observasi dilakukan 3 kali selama proses pembelajaran. Peneliti mengikuti kegiatan belajar mengajar dari awal sampai akhir pembelajaran. Peneliti juga melakukan analisis dokumen seperti RPP, silabus, buku guru dan buku siswa serta buku latihan siswa. Data yang telah dikumpulkan melalui teknik wawancara, observasi, serta analisis dokumen selanjutnya dianalisis. Pada penelitian ini, untuk menganalisis data peneliti menggunakan model Milles and Huberman dengan 3 tahapan yaitu reduksi data, penyajian data, dan penarikan kesimpulan.

\section{HASIL DAN PEMBAHASAN PENELITIAN}

Pada pelaksanaan kurikulum 2013 melalui pembelajaran tematik menekankan siswa berpartisipasi secara aktif dalam kegiatan pebelajaran sehingga diharapkan dapat memperoleh pengalaman langsung dan mengkonstruksi pengetahuannya sendiri sebagai suatu hasil yang dipelajarinya. Kurikulum 2013 yang masih tergolong baru, pada pelaksanaannya masih belum berjalan sesuai dengan rencana dikarenakan kesulitan dalam mengimplementasikan kurikulum yang dilakukan dengan pendekatan tematik dalam pembelajaran. Hal ini juga sebagian besar disebabkan oleh kurangnya pelatihan yang menyeluruh bagi instruktur pada pembelajaran 2013. Terlebih adanya Surat Edaran No. 4 tahun 2020 dari menteri pendidikan dan kebudayaan yang mengajurkan seluruh kegiatan di satuan pendidikan harus distance learning dan seluruh penyampaian materi akan disampaikan secara daring kepada siswa yg berada di rumah masing-masing.

Berdasarkan hasil yang diperoleh dari penelitian analisis kesulitan dalam dalam implementasi pembelajaran tematik secara daring (online) pada masa pandemi Covid-19 di Sekolah Dasar Kota Baubau dapat diketahui sebagai berikut:

1. Implementasi Pembelajaran Tematik di Sekolah Dasar Kota Baubau

Berdasarkan hasil wawancara dengan beberapa guru kelas di Sekolah Dasar Kota Baubau, dapat diketahui bahwa kurikulum 2013 telah diterapkan untuk kelas 1 sampai kelas 6. Dalam implementasinya 
masih menjadi tantangan, proses pembelajaran tidak bisa dikatakan sempurna karena peralihan dari kurikulum sebelumnya. Pada implementasi pembelajaran tematik secara daring di masa pandemi ini guru harus mampu dalam merancang, melaksanakan, dan mengevaluasi pembelajaran serta guru juga menggunakan media pembelajaran yang dapat di akses oleh siswa dengan baik. Adapun di Sekolah Dasar Kota Baubau guru masih belum sepenuhnya guru memahami bagaimana proses pembelajaran secara tematik yang akan diajarakan kepada peserta didik secara daring. Hal ini disebabkan karena tidak semua guru memiliki kesempatan untuk melakukan pelatihan di bidang ini dan kemampuan melaksanakan pembelajaran secara daring. Pelaksanaan pembelajaran tematik di Sekolah Dasar Kota Baubau dilakukan menggunakan aplikasi WhatsApp Group dengan tujuan karena lebih mudah diakses oleh siswa. WhatsApp yaitu media sosial online yang familiar dimiliki oleh kalangan pelajar, karena menjadi aplikasi yang sering digunakan untuk berkomunikasi melalui smartphone (Di \& Pandemi, 2021). Sebelum pelaksanaan pembelajaran hal yang tidak dilupakan guru yaitu membuat rencana pelaksanaan pembelajaran atau RPP. RPP yaitu rancangan pembelajaran yang dubuat oleh guru untuk melaksanakan proses pembelajaran.(Kasah, Fadillah, Studi, Matematika, \& Pontianak, 2014).

2. Analisis Kesulitan dalam implementasi pembelajran tematik secara daring dimasa pandemi Covid-19 Pembelajaran tematik mengharuskan guru berpatisipasi dan berperan aktif untuk meningkatkan kompetensi dan mengembangkan pengeetahuan, wawasam serta keterampilannya berkaitan dengan pembelajaran tematik di sekolah dasar. Guru diharapkan selalu mampu menghasilkan bahan ajar dengan upaya terbaiknya dan dengan memanfaatkan segala sesuatu yang ada. Oleh karena itu sudah sepantasnya guru berusaha untuk menjalankan tugasnya dengan maksimal. (Anshory, Saputra, \& Amelia, 2018) Pembelajaran tematik merupakan salah satu model pembelajaran terpadu (integrated instruction) yang merupakan suatu sistem pembelajaran dan memungkinkan siswa secara individu maupun kelompok, aktif menggali, dan menemukan konsep dan prinsip-prinsip keilmuan secara holistik, bermakna, serta autentik. Akan tetapi, di dalam pelaksanaannya tidak semua berjalan dengan baik. Masih banyak siswa yang mengalami kesulitan pada pembelajaran tematik. Di Sekolah Dasar Kota Baubau, kesulitan pada pembelajaran tematik yang dialami siswa kurang antusias dalam pembelajaran tematik yang dilaksanakan secara daring. Hal serupa disampaiakan (Cahyani et al., 2020) berkaiatan dengan tugas guru menghasilkan bahan ajar yang sesuai dan dapat diakses dengan mudah oleh siswa yang melakukan kegiatan belajar dari rumah secara daring, jika hal ini dapat dilakukan dengan kreativitas oleh pengajar, maka akan dapat pula meningkatkan kreativitas dan motivasi belajar siswa.

Pentingnya penggunaan berbagai media pembelajaran ditonjolkan dalam tema teori pembelajaran, namun pada kenyataannya guru tidak mendalami media pembelajaran daring. Guru sering mengandalkan buku pedoman guru sebagai satu-satunya sumber informasi mereka. Hal ini tentu saja dapat menyebabkan pembelajaran tidak berlangsung dengan efektif dan penyampaian materi yang masih kurang dipahami oleh siswa sehingga mengakibatkan kurangnya minat belajar siswa. Guru hendaknya meningkatkan kreativitas belajar untuk meningkatkan minat belajar siswa sehingga pembelajaran dapat berlangsung dalam suasana yang damai dan tujuan pembelajaran dapat tercapai. Guru harus dapat menempatkan dirinya dalam proses pembelajaran sebagai pemegang penting manajemen pembelajaran.

Proses pembelajaran tematik secara daring di Sekolah Dasar Kota Baubau selama pandemi Covid-19 merupakan suatu hal yang baru dan menjadi tantangan bagi guru dalam mengajarkan kepada siswa. Sekilas, pembelajaran yang dilakukan secara daring ini terlihat mudah karena dengan memiliki Smartphone atau laptop, maka pembelajaran akan berlangsung, tetapi pada kenyataannya, tidak mudah karena terdapat hambatan/masalah dan kesulitan yang terjadi dalam pembelajaran daring selama pandemi Covid-19. Adapun Kesulitan-kesulitan yang dialami oleh guru dalam mengimplementasikan pembelajaran tematik secara daring berikut: 
a. Strategi yang digunakan guru dalam pembelajaran daring masih kurang sesuai.

Pembelajaran online atau yang sering disebut pembelajaran daring merupakan suatu pembelajaran yang dilaksanakan secara jarak jauh dengan pemanfaatan teknologi seperti Smarthphone, laptop, tablet, maupun Komputer. Dalam hal ini guru dituntut agar dapat menggunakan strategi yang sesuai dengan kegiatan pembelajaran daring. tetapi, beberapa guru menggunakan strategi yang masih belum sesuai sehingga berdampak pada antusias siswa dalam mengikuti pembelajaran. Hal ini dikarenakan dengan kebiasaan guru yang menggunakan strategi pembelajaran secara tatap muka, sehingga saat melakukan pembelajaran daring mengalami kesulitan mencari stategi belajar yang sesuai dengan materi yang akan disampaikan kepada siswa sehingga tidak membuat siswa bosan dan mudah memahami materi pelajaran. sebagaiamana pendapat (Bondowoso, 2018) bahwa hambatan pembelajaran daring adalah strategi. Oleh karena itu, guru harus memikirkan strategi agar anak-anak bisa keluar dari zona kebosanan mereka, yaitu harus bisa menciptakan pembelajaran daring yang menarik bagi siswa.

\section{b. Kemampuan Peggunaan Teknologi Yang Masih Kurang}

Implementasi pembelajaran daring mengharuskan setiap guru dapat menggunakan aplikasi-aplikasi pembelajaran online dengan baik. Kenyataannya masih ada beberapa guru yang belum mampu menggunakan aplikasi pembelajaran daring. Seperti yang terjadi di Sekolah Dasar Kota Baubau selama proses pembelajaran guru menggunakan aplikasi WhatsApp. Melalui aplikasi WhatsApp guru dapat mengirimkan tugas dalam berbagai format dokumen seperti Ms. Word, Ms. Power Point, link video, pesan suara, dan format lainnya. Tetapi masih ada guru yang hanya mengirimkan foto materi dan tugas yang harus dikerjakan pada hari itu dan mengirimkannya di grup WhatsApp kelas. Hal ini dikarenakan kemampuan guru dalam menggunakan perangkat atau aplikasi-aplikasi yang dapat menunjang kegiatan pembelajaran online masih kurang. Untuk mengatasi hal ini guru bekerjasama dengan orang tua siswa dalam membuat tugas atau melaporkan perkembangan siswa belajar dari rumah. (Santaria, 2020), Bagi guru sekolah dasar guru belum memiliki kesiapan dari pembelajaran tatap muka ke pembelajaran daring. Selain itu, guru juga kurang menguasai teknologi padahal pembelajaran daring adalah pembelajaran yang menggunakan internet sebagai satu-satunya sarana. Hal ini menyebabkan penyampaian materi pembelajaran menjadi terhambat.

\section{c. Kesulitan guru dalam mengevaluasi pembelajaran tematik}

Implementasi pembelajaran tematik yang dilaksanakan secara daring dengan penggunaan media pembelajaran berupa aplikasi WhatsApp menyulitkan guru dalam melakukan penilaian (sikap, pengetahuan, keterampilan) hal ini dikarenakan guru tidak dapat menilai siswa secara langsung dengan melihat kegiatan pembeljaran yang dilakukan siswa, mengetahui sikap, pengetahuan, keterampilan yang dimiliki oleh setiap siswa. Sebagaimana pelaksanaan pembelajaran daring menimbulkan masalah baru dalam hal penilaian siswa. Hal ini karena siswa memperolah nilai maksimal ketika diberi soal yang menjadi pertanyaan guru, apakah nilai tersebut karena siswa benar-benar memahami materi atau mendapat bantuan orang dewasa ketika pengerjaannya. Sehingga guru tidak dapat menilai ketercapaian pembelajaran secara obyektif seduai dengan kemampuan siswa. Dari sisi afektif, guru juga mengalami kesulitan penilaian. Hal serupa disampaiakan (Pratiwi, 2021)Biasanya penilaian afektif terjadi secara alamiah ketika siswa berinteraksi, berkomunikasi dan bersosialisasi dengan teman. Adanya pembelajaran daring, menghilangkan sosialisasi siswa dengan siswa secara langsung. Disisi lain juga meragukan kejujuran siswa dalam mengerjakan tugas yang diberikan oleh guru.

\section{d. Keterbatasan Fasilitas Yang Dimiliki Oleh Siswa}

Implementasi pembelajaran tematik secara daring dengan penyampaian materi pelajaran kepada siswa yang tidak memiliki fasilitas yang menunjang dalam melaksanakan kegiatan pembelajaran menjadi salah satu 
penyebab kesulitasn guru. Di Sekolah Dasar Kota Baubauu masih terdapat siswa yang tidak memiliki fasilitas yang dapat digunakan dalam pembelajaran daring seperti smartphone sehingga tidak dapat menerima materi pelajaran yang disampaikan oleh guru melalui aplikasi yang digunakan secara daring. Hal serupa disampaikan (Handarini \& Wulandari, 2020) Pembelajaran daring membutuhkan sarana dan prasarana yang memadai, salah satunya seperti laptop, komputer, smartphone, dan jaringan internet. Hal serupa disampaikan (Huzaimah \& Amelia, 2021)Tentunya ini menjadi hambatan dalam belajar siswa yang dialami, karena tidak semua siswa memiliki fasilitas pembelajaran daring. Salah satu yang menyebabkan karena perekonomian yang rendah. Dalam hal ini, guru memberikan solusi kepada siswa yang tidak memiliki Smartphone untuk datang ke rumah teman terdekat yang memiliki Smartphone dan dapat belajar bersama. Guru juga memasukkan orangtua siswa ke dalam grup WhatsAppkelas yang sama dengan siswa. Sehingga orang tua mengetahui kegiatan belajar siswa dan mengontrol siswa dalam meneyelesaikan tugas yang diberikan guru.

\section{KESIMPULAN}

Pandemi Covid-19 mengakibatkan terjadi perubahan di berbagai aspek kehidupan, salah satunya dalam dunia pendidikan. Perubahan pembelajaran di Sekolah Dasar Kota Baubau yang biasanya dilaksanakan secara tatap muka menjadi pembelajaran daring. Berdasarkan hasil yang diperoleh dari penelitian implementasi pembelajaran tematik secara daring di Sekolah Dasar Kota Baubau dimasa pandem Covid-19 dapat disimpulkan bahwa pada perencanaan pembelajaran tematik yaitu pada RPP yang dibuat guru kadang belum sesuai dengan pelaksanaannya tergantung kondisi dan fleksibilitas waktu/guru masih kesulitan mengalokasikan waktu pembelajaran secara daring. Adapun pada pelaksanaan pembelajaran tematik secara daring guru masih belum menggunakan strategi yang sesuai serta mengalami kendala dalam menggunakan media/aplikasi dalam pembelajaran daring sehingga reaksi atau respon siswa kurang antusias/ kurang tertarik dengan materi yang disampaikan oleh guru, mengakibatkan siswa mulai bosan/jenuh, masih kurangnya ketersediaan sarana dan prasarana, guru tidak dapat langsung berkomunikasi dengan siswa sehingga siswa harus lebih memahami materi secara mandiri, banyak siswa saat pembelajaran daring akan dilaksanakan siswa belum memiliki smartphone dan akses internet. Begitupula dengan evaluasi atau penilaian pembelajaran daring dimana guru masih mengalami permasalahan dan kesulitan dalam menilai siswa yang diajar secara daring.

\section{UCAPAN TERIMA KASIH}

Penulis mengucapkan terima kasih yang sebesar-besarnya kepada Bapak/ibu guru di Sekolah Dasar Kota Baubau sebagai responden dalam penelitian ini dan pihak-pihak yang sudah membantu dalam menyelesaikan penelitian ini, juga kepada pihak jurnal Edukatif yang telah membantu dalam mempublish artikel.

\section{DAFTAR PUSTAKA}

Alvina, O. D., Wandini, R. R., Siahaan, M. Y., \& Siregar, A. H. (2021). No Title. 10(1), 141-153.

Anhusadar, L. O. (2021). Efektivitas Pembelajaran Online Pendidik Paud Di Tengah Pandemi Covid 19. 5(1), 686-697. Https://Doi.Org/10.31004/Obsesi.V5i1.699

Anshory, I., Saputra, S. Y., \& Amelia, D. J. (2018). Pembelajaran Tematik Integratif Pada Kurikulum 2013 Di Kelas Rendah Sd Muhammadiyah 07 Wajak. 4, 35-46.

Anugrahana, A. (2020). Hambatan, Solusi Dan Harapan: Pembelajaran Daring Selama Masa Pandemi 
4399 Analisis Kesulitan Implementasi Pembelajaran Tematik pada Masa Pandemi Covid-19 di Sekolah DasarIrsan, Andi Lely Nurmaya. G, Tri Yulan

DOI: https://doi.org/10.31004/edukatif.v3i6.1475

Covid-19 Oleh Guru Sekolah Dasar. 282-289.

Batubara, H. H. (N.D.). Implementasi Pembelajaran Tematik Di Sekolah Dasar Pada Masa Pandemi Covid19 Ditinjau Dari Teori.

Bondowoso, I. I. I. (2018). Problematika Pembelajaran Tematik Terpadu. 1(1), 45-61.

Cahyani, A., Listiana, I. D., Puteri, S., Larasati, D., Islam, U., Sunan, N., ... Belajar, M. (2020). Motivasi Belajar Siswa Sma Pada Pembelajaran Daring Di Masa Pandemi Covid-19. 3(01), 123-140.

Di, J., \& Pandemi, M. (2021). Pemanfaatan Teknologi Pembelajaran Dalam Jaringan Di Masa Pandemi Covid-19 Yosi Intan Pandini Gunawan \& Asep Amaludin 1. 11(1), 686-697.

Education, E., Dafit, F., Ramadan, Z. H., \& Riau, U. I. (2020). Jurnal Basicedu. 4(4), 1429-1437.

Handarini, O. I., \& Wulandari, S. S. (2020). Pembelajaran Daring Sebagai Upaya Study From Home ( Sfh ) Selama Pandemi Covid 19 Pembelajaran Daring Sebagai Upaya Study From Home ( Sfh ) ... .. 8(1), 496-503.

Huzaimah, P. Z., \& Amelia, R. (2021). Hambatan Yang Dialami Siswa Dalam Pembelajaran Daring Matematika Pada Masa Pandemi Covid-19. 05(01), 533-541.

Islam, U., \& Antasari, N. (2021). Edukatif: Jurnal Ilmu Pendidikan Hubungan Konsentrasi Belajar Siswa Terhadap Prestasi Belajar Peserta Didik Pada Masa Pandemi Covid-19 Di Sekolah Dasar Riinawati. 3(4), 2305-2312.

Kasah, E., Fadillah, S., Studi, P., Matematika, P., \& Pontianak, S. P. (2014). Berbasis Pendekatan Open Ended Terhadap Kemampuan Representasi Matematis Mahasiswa The Effect Of Using Differential Calculus Textbook Based On Open Ended Approach Towards Students' Mathematical Representation Ability. 20(September), 340-352.

Nu, A., Kecamatan, N., Kabupaten, P., Kepada, D., Tarbiyah, F., Purwokerto, I., ... Pendidikan, S. (2020). Oleh: Yunia Caesar Priastuti Fakultas Tarbiyah Dan Ilmu Keguruan Institut Agama Islam Negeri (Iain ) Purwokerto : Yunia Caesar Priastuti.

Nurbaeti, D., Gustiawati, S., \& Khaldun, U. I. (2021). Edukatif: Jurnal Ilmu Pendidikan Pengaruh Kreativitas Guru Dalam Pembelajaran Daring Terhadap Hasil Belajar Siswa Pada Mata Pelajaran Pendidikan Agama Islam. 3(4), 1409-1417.

Pelajaran, M., Di, P., Sains, S. M. A., \& An, Q. (N.D.). Implemntasi Teori Belajar Konstruktivisme Vygotsky Pada. 5(01). Https://Doi.Org/10.29240/Belajea.V5

Pratiwi, A. S. (2021). Pelaksanaan Pembelajaran Daring Dalam Masa Darurat Penyebaran Covid-19 Di Sd Ti 030 Batu Belah Kelas Vi. 5, 766-773.

Santaria, R. (2020). Dampak Pandemi Covid-19 Terhadap Proses Pengajaran Bagi Guru Dan Siswa Pendahuluan. 3(2), 289-295.

Sari, I. K., Astuti, S., Guru, P., Dasar, S., Kristen, U., \& Wacana, S. (2021). Edukatif: Jurnal Ilmu Pendidikan Efektivitas Pembelajaran Luring Dan Daring Terhadap Hasil Belajar Tematik Siswa Di Sekolah Dasar. 3(4), 1717-1723.

Wardah, R., \& Farisia, H. (2021). Edukatif: Jurnal Ilmu Pendidikan Pembelajaran Daring Pada Masa Pandemi Covid-19: Implementasinya Pada Sekolah Menengah Pertama. 3(4), 2008-2017.

Yunitasari, R., \& Hanifah, U. (2020). Edukatif: Jurnal Ilmu Pendidikan Pengaruh Pembelajaran Daring Terhadap Minat Belajar Siswa Pada Masa Covid-19. 2(3), 232-243. 